\title{
The Role of Membrane Lipids in the Survival of Red Cells in Hereditary Spherocytosis
}

\author{
R. A. Cooper and J. H. JANDL \\ From the Thorndike Memorial Laboratory and 2nd and 4th (Harvard) \\ Medical Services, Boston City Hospital, and the Department of Medicine, \\ Harvard Medical School, Boston, Massachusetts 02118
}

A B S T R A T Red cells in hereditary spherocytosis (HS) have a decreased ratio of membrane surface area to cell volume and therefore a spheroidal shape. This abnormality in shape predisposes them to pooling and destruction in the spleen. Although splenectomy prevents hemolysis in HS, the red cell defect, as manifested by spheroidicity, increased autohemolysis, excesive permeability to sodium, and hypermetabolism, persists. The role of membrane lipids in these manifestations in vitro and in cell survival in vivo was examined.

Before splencetomy, and in spite of the presence of a young cell population, the cholesterol and phospholipid content of $\mathrm{HS}$ red cells is decreased. After splenectomy lipid values are similar to those obtained in normal subjects with spleens. However, after splenectomy for conditions other than HS the lipid content of red cells is greater than normal. Thus, when compared with the red cells of patients without HS who have also undergone splenectomy, HS cells after splenectomy are deficient in both cholesterol and phospholipid.

Obstructive jaundice causes an increase in membrane lipid, primarily cholesterol, and a decrease in the osmotic fragility of normal red cells. When $\mathrm{HS}$ red cells are transfused into patients with obstructive jaundice they also become less osmotically fragile. Moreover, when incubated in obstructive jaundice serum, they gain cholesterol. This acquisition of membrane lipid in vitro does not result in a change in their rate of glucose utilization or sodium efflux. However, the transformation to a less spheroidal shape in vivo permits them to traverse better the splenic circulation and survive longer.

This work was presented in part at the Annual Meeting of the American Society of Hematology, December 1967, and published in abstract form in Clin. Res. 15: 274 and in Blood. 30: 883 .

Received for publication 19 November 1968.

\section{INTRODUCTION}

The destruction in vivo of hereditary spherocytosis (HS) red cells appears to result from two major factors: a tendency for the pooling of HS cells in the spleen (1-3), and an inordinate susceptibility to damage under the adverse conditions existing in the splenic milieu ${ }^{1}(4-6)$. $\mathrm{HS}$ red cells are more spheroidal and osmotically fragile than normal even as they leave the bone marrow (7). It is generally held that splenic pooling occurs because of the difficulty with which such spheroidal cells traverse the slit-like stomata leading from pulp to splenic sinuses $(1-3,8)$, the average diameters of which have been estimated at $3 \mu$ (9). As they circulate in patients with spleens, HS cells become progressively more spheroidal, until they finally undergo destruction (7). The mechanism of this increase in spheroid city, termed "splenic conditioning" (1), is not entirely clear. Splenectomy, however, almost invariably causes a cessation of conditioning and hemolysis, despite the persistence of a spheroidal shape (3).

HS red cells lose membrane lipid excessively under conditions in vitro ${ }^{1}$ (5) which may be analogous to the stagnant conditions of splenic pooling in vivo (10). This leads to a loss of surface area $(11,12)$ and therefore to an increase in osmotic fragility. In patients with spleens, the lipid content of HS red cells is less than normal (5); however, after splenectomy red cell lipids in HS are the same as those in red cells from normal subjects with intact spleens $(5,13,14)$. Thus, whereas depletion of membrane lipid may explain, in part, the events of splenic conditioning and eventual cell destruction, the fact that after splenectomy HS red cells have a lipid content that is "normal" has excluded a quantitative abnormality in red cell lipids from consideration as the basic defect in HS. However, the effect of splenectomy, per se, on red cell lipids has not been previously studied, although flat, osmotically resistant "target cells" 
with increased surface area have long been known to occur in normal subjects after splenectomy (15).

Lipids of the red cell membrane are not static structural units; rather they are in a dynamic exchange with their serum counterparts $(16,17)$. Moreover, quantitative changes in red cell lipids, cholesterol in particular, can occur as a result of certain pathological alterations in serum lipids $(11,12,18-20)$. The acquisition of cell lipid in obstructive jaundice is of interest because it occurs rapidly, leads to proportional changes in membrane surface area, and does not impair red cell survival in vivo $(12,21)$.

The present studies were undertaken to reexamine the lipid content of HS red cells and to determine the influence of lipid acquisition, as occurs in obstructive jaundice, on the physiology of these red cells in vivo and in vitro.

\section{METHODS}

Selection of patients and normal subjects. Patients with HS were selected on the basis of red cell morphology, osmotic fragility, autohemolysis, and, in all but one case, family history. (Data obtained from the patient who lacked a family history appear only in Table I.) Patients who had undergone splenectomy for conditions other than HS had the diagnoses of: idiopathic thrombocytopenic purpura-9, lymphosarcoma of the spleen-2, lupus erythematosus-1, and Coombs positive hemolytic anemia (in remission at the time of study) 2. Splenectomies had been performed from 3 months to $20 \mathrm{yr}$ previously in both the HS and the non-HS groups.

Patients with obstructive jaundice had the diagnoses of: carcinoma of the bile ducts-1, carcinoma of the pancreas-2, and carcinoma of the bile ducts partially relieved to $T$-tube drainage-1. Normal subjects were hematologically normal and had no evidence of hepatic dysfunction.

Evaluation of red cells from patients before and after splenectomy and from normal subjects. Blood was collected in balanced oxalate, and reticulocytes (22) and mean cell volume (MCV) were measured. After three saline washes to remove white cells and platelets, quadruplicate aliquots of red cells were extracted with isopropanol and chloroform (23) for measurement of cholesterol (24) and phospholipid (25) with standard errors (95\% confidence limits) of 1.8 and $2.4 \%$, respectively.

Incubations in vitro. Normal and HS red cells from freshly drawn, heparinized, or defibrinated blood were thrice washed with Hank's balanced salt solutions. Triplicate 1.0-2.0 ml aliquots were incubated at cell concentrations of $5-10 \%$ in equal portions of Hank's and serum containing penicillin, $500 \mathrm{U} / \mathrm{ml}$, in a $37^{\circ} \mathrm{C}$ atmosphere in capped $16 \times$ $150 \mathrm{~mm}$ tubes shaking at 130 oscillations/min. Sera had been dialyzed against Hank's solution containing glucose 100 $\mathrm{mg} / 100 \mathrm{ml}$ and brought to $\mathrm{pH} 7.4$ with $\mathrm{CO}_{2}$ before incubation. Sera designated "heated" had been heated to $56^{\circ} \mathrm{C}$ for $30 \mathrm{~min}$. Red cell lipids, measured as described above, autohemolysis (26), osmotic fragility $(1,12)$, and glucose consumption (27) were determined. For the measurement of sodium efflux, red cells were incubated at a cell concentration of $7 \%$ in various sera, each containing $1 \mu \mathrm{c}{ }^{22} \mathrm{Na} / 15 \mathrm{ml}$ cell suspension. After $20 \mathrm{hr}$ at $37^{\circ} \mathrm{C}$ the red cells were washed thrice with Earle's solution and incubated at a hematocrit of $25 \%$ in this buffer. ${ }^{22} \mathrm{Na}$ efflux was measured over $3 \mathrm{hr}$ (4).

Studies in vivo. Red cells from a single patient with HS who had undergone splenectomy $7 \mathrm{yr}$ previously were used in all studies of HS red cells in vivo. This patient had the typical changes of red cell morphology, osmotic fragility, and autohemolysis. $30 \mathrm{ml}$ of blood was collected in acid-citrate-dextrose, labeled with $200 \mu \mathrm{c}$ of $\mathrm{Na}_{2}{ }^{51} \mathrm{CrO}$ (Abbott Laboratories) (28), washed once with saline, and, within $2 \mathrm{hr}$ of collection, transfused into the subject studied. Compatibility between donor and recipient was determined by the Coombs cross-matching procedure (29). At intervals after transfusion, the survival of the transfused cells and the osmotic fragility of both the transfused cells and the recipient's own cells were determined as described previously $(12,30)$. Cell survivals are expressed as per cent of the radioactivity in a sample taken $5 \mathrm{~min}$ after injection. This 5 min value agreed within $\pm 10 \%$ with the theoretical $100 \%$ calculated from total ${ }^{51} \mathrm{Cr}$ counts injected assuming a blood volume of $7 \%$ of body weight.

There was no history of prior transfusion in the normal recipients or in two of the patients with complete biliary tract obstruction (represented by the two upper curves in Fig. 1). The third patient with complete obstruction had received transfusions on multiple occasions in the past during surgery for an unrelated, neurologic disease. The patient with partial obstruction had received transfusions at the time of his biliary tract surgery 1 month before study.

The survival of heated, normal red cells was determined simultaneously in three normal subjects and one patient with obstructive jaundice, using one cohort of red cells labeled with $\mathrm{Na}_{2}{ }^{51} \mathrm{CrO}_{4}$ and then heated at $50^{\circ} \mathrm{C}$ for $25 \mathrm{~min}$. Body surface counts over the spleen, liver and precordium were measured at $2 \mathrm{hr}$ after injection (31-33). Cell survival is expressed as per cent of ${ }^{51} \mathrm{Cr}$ injected assuming a blood volume of $7 \%$ of body weight.

All subjects who served as recipients of HS or heated normal red cells were apprised of the experimental details and gave their free consent. The protocol for these experiments was approved by the Review Committee, Clinical Center, Thorndike Memorial Laboratory, Boston City Hospital, Boston, Mass.

\section{RESULTS}

The effect of splenectomy on red cells in conditions other than HS. Because previous studies had compared red cell lipids from patients with HS who lacked spleens with those of normal subjects with spleens $(5,13,14)$, the effect of splenectomy, per se, was evaluated. Measurements were made of the lipid content of red cells from 14 patients who had undergone splenectomy for reasons other than HS (Table I). When compared with red cells from normal subjects with intact spleens, there was a $23.3 \%$ increase in cholesterol content, a $12.6 \%$ increase in phospholipid content, and a $9.4 \%$ increase in the cholesterol:phospholipid ratio. All of these differences were highly significant $(P<0.001)$. Moreover, these increases in cell lipid content beyond the normal range occurred in each subject tested and were not related to an increase in either MCV or the number of reticulocytes. There was no accompanying difference in the serum concentrations of either cholesterol (pa- 
TABLE I

Effect of Splenectomy on Red Cell Lipids*

\begin{tabular}{|c|c|c|c|}
\hline Number. ................... & $\begin{array}{l}\text { Normals } \\
\text { with spleens } \\
\quad 11\end{array}$ & $\begin{array}{c}\text { Non-HS } \\
\text { after splenectomy } \\
14\end{array}$ & $\begin{array}{c}\text { HS } \\
\text { after splenectomy } \\
10\end{array}$ \\
\hline Hematocrit, $\%$ & $44.2 \pm 3.8$ & $40.2 \pm 2.8$ & $42.8 \pm 2.7$ \\
\hline Mean cell volume, $\mu^{3}$ & $82.7 \pm 2.9$ & $84.3 \pm 4.9$ & $78.2 \pm 6.2$ \\
\hline Reticulocytes, $\%$ & $0.5 \pm 0.9$ & $1.3 \pm 1.7$ & $0.6 \pm 0.9$ \\
\hline $\begin{array}{l}\text { Red cell cholesterol, } \\
\mu \mathrm{g} / 10^{8} \text { cells } \text { (range) }\end{array}$ & $\begin{array}{r}13.41 \pm 0.44 \\
(12.45-14.57)\end{array}$ & $\begin{array}{r}16.54 \pm 0.34 \\
(15.24-19.91)\end{array}$ & $\begin{array}{r}13.63 \pm 0.67 \\
(11.88-14.84)\end{array}$ \\
\hline $\begin{array}{l}\text { Red cell lipid phosphorus, } \\
\mu \mathrm{g} / 10^{\circ} \text { cells (range) }\end{array}$ & $\begin{array}{r}12.64 \pm 0.26 \\
(12.28-13.13)\end{array}$ & $\begin{array}{r}14.24 \pm 0.33 \\
(13.39-16.43)\end{array}$ & $\begin{array}{r}12.01 \pm 0.68 \\
(10.84-13.97)\end{array}$ \\
\hline Cholesterol:Lipid phosphorus & $10.6 \pm 0.3$ & $11.6 \pm 0.5$ & $11.1 \pm 0.4$ \\
\hline
\end{tabular}

* Data are expressed as mean $\pm \mathrm{SE}, 95 \%$ confidence limits. HS = hereditary spherocytosis.

tients $=210 \pm 44 \mathrm{mg} / 100 \mathrm{ml}$; normals $=185 \pm 20$ ) or phospholipid (patients $=246 \pm 64 \mathrm{mg} / 100 \mathrm{ml}$; normals $=256 \pm 36$ ).

The lipid content of $H S$ red cells. The cholesterol and phospholipid content of red cells from 10 patients with HS who had undergone splenectomy at least 5 months previously was measured (Table I). The lipid content of these cells was similar to that of red cells from 11 normal subjects with intact spleens (Table I), as previously reported $(5,13,14)$. However, when compared with red cells from patients whose spleens had been removed for reasons other than HS, the HS cells had a deficiency of cholesterol that averaged $19.3 \%$ and of phospholipid that averaged $15.7 \%$. These lipid deficiencies were highly significant $(P<0.001)$. The average $\mathrm{MCV}$ in the HS patients was $7 \%$ less than in the non-HS patients. However, the MCV in two patients in the HS group was particularly low and exceeded by greater than 2 SD the average MCV of the other eight HS patients. When these two patients were excluded,

TABLE II

Effects of Obstructive Jaundice in a Patient with HS

\begin{tabular}{|c|c|c|c|c|c|}
\hline $\begin{array}{l}\text { Hospital } \\
\text { day }\end{array}$ & $\begin{array}{c}\text { Serum } \\
\text { bilirubin }\end{array}$ & $\begin{array}{c}\text { Serum } \\
\text { cholesterol }\end{array}$ & $\begin{array}{c}\text { Mean } \\
\text { osmotic } \\
\text { fragility }\end{array}$ & $\begin{array}{c}\text { Red cell } \\
\text { cholesterol }\end{array}$ & $\begin{array}{c}\text { Red cell } \\
\text { lipid } \\
\text { phosphorus }\end{array}$ \\
\hline & \multicolumn{2}{|c|}{$m g / 100 \mathrm{ml}$} & $\begin{array}{c}\mathrm{NaCl} \mathrm{g} / \\
100 \mathrm{ml}\end{array}$ & $\mu \mathrm{g} / 10^{8} \mathrm{cells}$ & $\mu g / 10^{\circ} \mathrm{cells}$ \\
\hline 1 & 11.5 & 310 & 0.427 & 一 & - \\
\hline 2 & 11.8 & - & 0.433 & 15.00 & 12.20 \\
\hline 5 & 13.5 & 435 & 0.416 & 16.50 & 13.00 \\
\hline 6 & 13.2 & - & 0.406 & - & - \\
\hline 12 & 5.0 & 440 & 0.453 & 一 & - \\
\hline 20 & 2.4 & 280 & 0.452 & 13.25 & - \\
\hline 27 & 3.2 & 215 & 0.448 & 12.80 & 12.20 \\
\hline 40 & 1.4 & 184 & 0.451 & 13.40 & 13.00 \\
\hline
\end{tabular}

the average MCV of the HS group was $81.4 \mu^{3}$. This is not significantly different from the average $\mathrm{MCV}$ in the non-HS patients. The deficiency of red cell cholesterol in these eight HS patients was $19.6 \%$ and of phospholipid, $15.2 \%$. Thus, the lipid deficiency in HS after splenectomy is not related to a difference in cell volume.

Two patients with HS were studied at the time of their splenectomies. Before splenectomy red cell cholesterol values were 12.40 and $12.39 \mu \mathrm{g} / 10^{8}$ cells, and lipid phosphorus values were 11.25 and $12.28 \mu \mathrm{g} / 10^{\circ}$ cells. Reticulocytes were 12 and $35 \%$. These lipid values are decreased an average of $7 \%$ as compared with normal subjects with intact spleens. Over the 1 st 4 days after splenectomy there was no change in the red cell lipid content. However, when measured again 3 months later when reticulocytes had fallen to 0.8 and $1.0 \%$, the red cell lipids had increased to values found in other patients with HS who lacked spleens (cholesterol, 13.42 and $13.56 \mu \mathrm{g} / 10^{8}$ cells and lipid phosphorus, 12.80 and $12.87 \mu \mathrm{g} / 10^{\circ}$ cells).

The influence of obstructive jaundice on $H S$ red cells in vivo. A $45 \mathrm{yr}$ old man with $\mathrm{HS}$ and an intact spleen was hospitalized because of jaundice due to a common duct stone, which he subsequently passed. The course of his liver function studies and the lipid content and osmotic fragility of his red cells is presented in Table II. His red cells became more resistant to osmotic lysis during the period of biliary tract obstruction, as had been observed $80 \mathrm{yr}$ previously in hematologically normal subjects (34). Concomitant with this change in osmotic fragility, there was an increase in red cell cholesterol but no significant change in red cell phospholipid. Reticulocytes remained between 5 and $9 \%$.

It was not possible to assess the influence that this alteration in membrane lipid had on cell survival during 

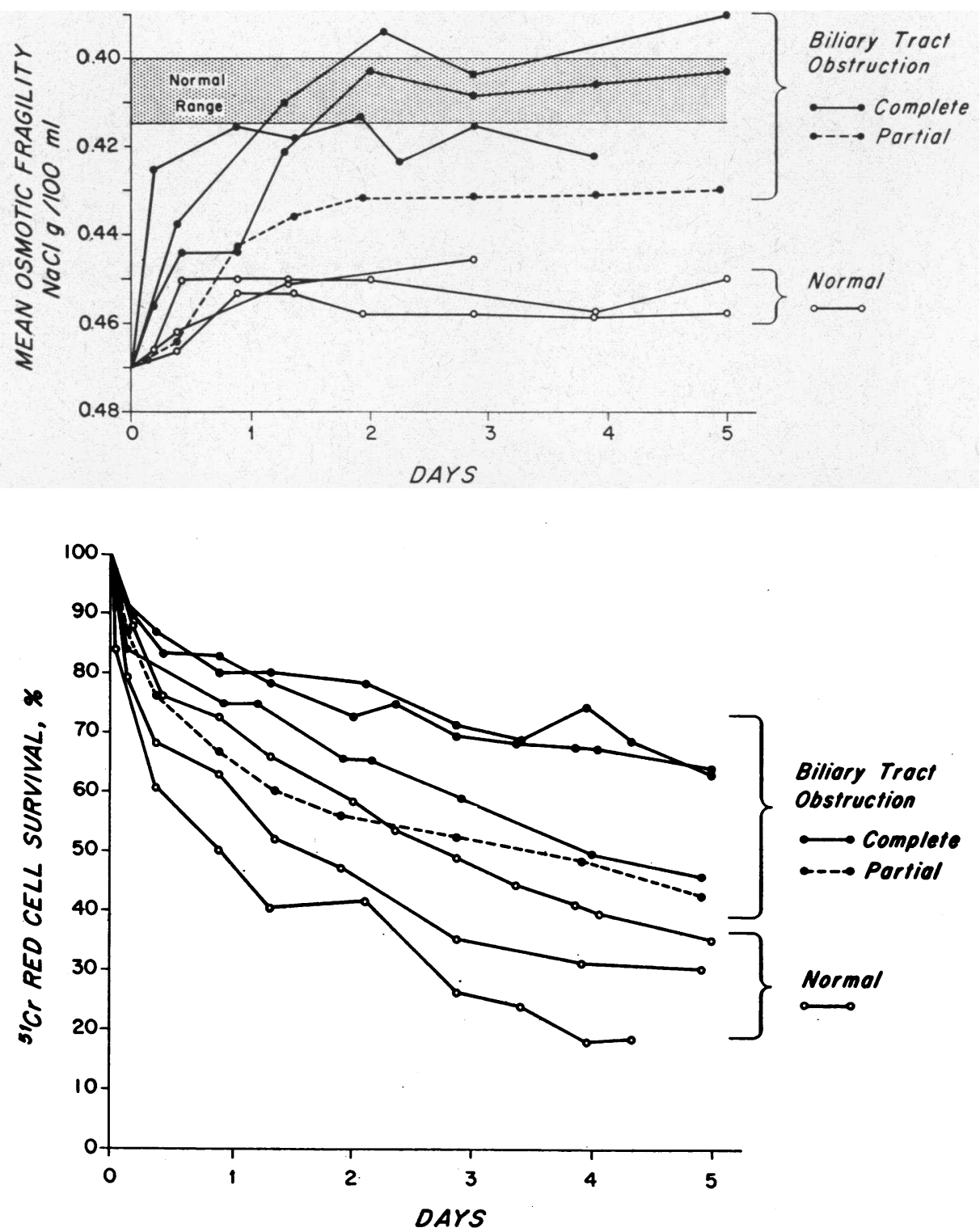

FIGURE 1 The effect of obstructive jaundice on the osmotic fragility and survival of hereditary spherocytosis (HS) red cells. Red cells from a patient with HS, who had previously undergone splenectomy, were labeled with ${ }^{51} \mathrm{Cr}$ and transfused into three normal subjects and four patients with obstructive jaundice, three of whom had complete obstruction. Mean osmotic fragility ( $50 \%$ lysis) and survival of the transfused cells are represented. There was a shift toward a normal osmotic fragility and a prolongation in survival of the HS cells after transfusion into patients with obstructive jaundice.

the transient episode of biliary tract obstruction described above. To study this, four hematologically normal patients with persistent biliary tract obstruction were transfused with ${ }^{51} \mathrm{Cr}$-labeled red cells from a patient with HS who had previously undergone splenectomy (Fig. 1). On three occasions a portion of these same red cells were simultaneously transfused into a normal subject.
All recipients had spleens. The mean osmotic fragilities of the recipients' red cells were: $0.40-0.41 \mathrm{~g} \mathrm{NaCl} / 100$ $\mathrm{ml}$ in the normal subjects, 0.37 in the patient with partial obstruction, and $0.31-0.34$ in the patients with complete obstruction. The mean osmotic fragility of the transfused HS red cells was 0.47 .

There was little change in the osmotic fragility of the 


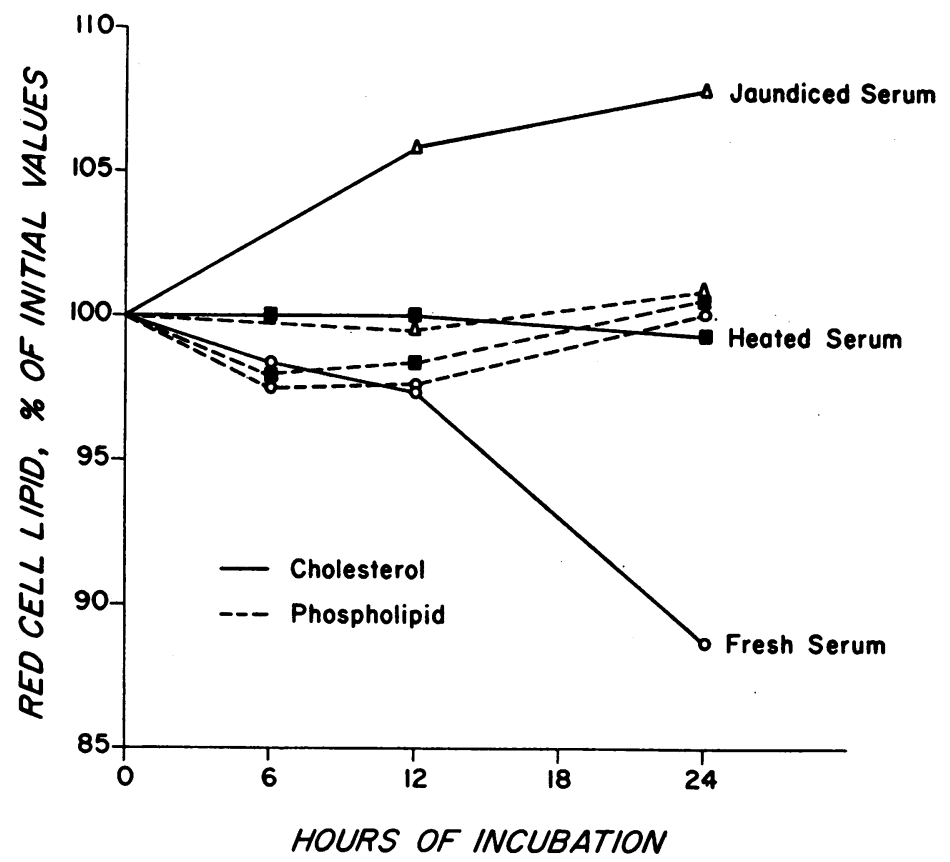

FIGURE 2 Effect of obstructive jaundice serum on HS red cells in vitro. HS red cells were incubated at a cell concentration of $6 \%$ at $37^{\circ} \mathrm{C}$ for $24 \mathrm{hr}$. Red cell cholesterol decreased in fresh, normal serum and this was prevented in heated, normal serum. Red cell cholesterol increased in serum from a patient with obstructive jaundice. No change in the red cell content of phospholipid occurred under any of these conditions.

HS red cells after transfusion in normal subjects, the slight decrease in fragility observed probably representing destruction of the most fragile cells. In the jaundiced subjects, however, the transfused HS cells became more resistant to osmotic lysis, and in two subjects they acquired a normal osmotic fragility. However, in none of these transfusions did the HS red cells actually acquire the osmotic fragility of the recipient's own target cells.

The ${ }^{51} \mathrm{Cr}$-half survival of the HS red cells averaged 1.9 days after transfusion into normal subjects. In contrast, survival in the jaundiced recipients was enhanced and correlated closely with the osmotic fragility change that had occurred. In the patient with partial biliary tract obstruction, in whom there was only a modest change in osmotic fragility, the ${ }^{51} \mathrm{Cr}$-half survival was prolonged to 3.9 days, whereas in the patients with complete obstruction it averaged 9.3 days. In the two patients with complete obstruction in whom the osmotic fragility shifted to within the normal range, the ${ }^{51} \mathrm{Cr}$-half survival was prolonged to 12.0 days. Normal ${ }^{51} \mathrm{Cr}$-half survivals by this method average 26 days $(12,28)$.

The effect of obstructive jaundice on spleen function was tested, since an inhibition of spleen sequestering function in obstructive jaundice could also cause a prolongation in red cell survival. Normal red cells labeled with ${ }^{51} \mathrm{Cr}$ were heated at $50^{\circ} \mathrm{C}$ for $25 \mathrm{~min}$ and transfused into three normal subjects and into one patient with complete biliary tract obstruction. The average halfsurvival in the three normal subjects was 107 min (75$170 \mathrm{~min}$ ) and in the jaundiced subject $103 \mathrm{~min}$. Splenic sequestration predominated in all subjects, the spleen: liver ratio at $2 \mathrm{hr}$ averaging $6.9(4.2-9.5)$ in the normals and 8.5 in the jaundiced subject. Thus, obstructive jaundice appears not to influence the sequestering function of the spleen.

Effect of obstructive jaundice sera on $H S$ red cells in vitro. When HS red cells were incubated at a cell concentration of $6 \%$ for $24 \mathrm{hr}$ (Fig. 2), they underwent changes in lipid content similar to that previously observed in normal red cells. In fresh serum they lost cholesterol, but not phospholipid, due to esterification of free cholesterol in serum by the serum enzyme, acyltransferase, and this was prevented by heating the serum to inactivate the enzyme (11). In serum from a patient with obstructive jaundice, however, they gained cholesterol. As has been observed in normal red cells (12), this gain in cholesterol in vitro was not associated with 
TABLE III

Effect of Obstructive Jaunaice Serum on Normal and Hereditary Spherocytosis (HS) Red Cells

\begin{tabular}{lccccc}
\hline & \multicolumn{2}{c}{ HS red cells } & & \multicolumn{2}{c}{ Normal red cells } \\
\cline { 2 - 3 } \cline { 5 - 6 } & Normal serum & Jaundiced serum & & Normal serum & Jaundiced serum \\
\hline Cholesterol, \% of initial value & +2.6 & +13.6 & & +0.3 & +15.7 \\
Phospholipid, \% of initial value & +0.4 & +2.6 & & +0.2 & +2.5 \\
Glucose consumption, $\mu$ mole $/ m l$ per $h r$ & 1.73 & 1.70 & & 1.40 & 1.38 \\
Na efflux, meq/liter per $h r$ & 2.89 & 3.15 & & 2.30 & 2.47 \\
\hline
\end{tabular}

any change in their content of phospholipid. The mean osmotic fragility of these HS cells after incubation in normal heated serum was $0.49 \mathrm{~g} \mathrm{NaCl} / 100 \mathrm{ml}$. This was increased to 0.52 in fresh serum but was decreased to 0.44 in obstructive jaundice serum.

HS red cells are not only deficient in surface area but they are also excessively permeable to sodium $(4,35)$. This leads to an increased rate of sodium extrusion and an accelerated rate of gucose consumption $(4,36)$. To test whether the beneficial effect of obstructive jaundice on HS cells in vivo was related to a change in osmotic fragility alone, or to an alteration in cell membrane permeability and glucose metabolism as well, red cells from two patients with HS who had undergone splenectomy and from two normal subjects were incubated in media containing normal heated serum or heated serum from a patient with obstructive jaundice. Glucose consumption was measured during a $12 \mathrm{hr}$ period beginning $8 \mathrm{hr}$ after the start of incubation, sodium efflux after $20 \mathrm{hr}$ incubation, and cell lipids before and at the end of $20 \mathrm{hr}$ incubation (Table III). In normal serum the rate of glucose consumption, expressed as $\mu$ moles $/ \mathrm{ml}$ packed cells per hr, averaged 1.40 in normal cells and 1.73 in HS cells. When incubated in obstructive jaundice serum there was no significant change in these rates in spite of an increase in red cell cholesterol that averaged $13.6 \%$ in HS cells and $15.7 \%$ in normal red cells. Similarly, there was no significant change in the rate of sodium efflux which averaged $26 \%$ greater in HS than in normal red cells when incubated in normal serum and $27 \%$ greater when incubated in jaundiced serum. Thus, the acquisition of lipid by HS cells in obstructive jaundice extends their membrane surface area but does not correct either their increased permeability to sodium or their increased rate of glycolysis.

The interrelationship between autohemolysis and the lipid changes induced by obstructive jaundice serum was assessed during a prolonged incubation of HS red cells at a cell concentration of $5 \%$ in media containing fresh sera obtained from a normal subject and from two patients with obstructive jaundice. A low hematocrit was used to provide time for maximum changes in red cell lipids to occur before glucose exhaustion. Red cell lipids were measured at $48 \mathrm{hr}$, a time before hemolysis, and per cent hemolysis was measured at $96 \mathrm{hr}$. Red cell cholesterol was decreased $22.0 \%$ in fresh, normal serum, whereas in jaundiced sera it was increased by an average of $10.1 \%$. No significant changes occurred in red cell phospholipid. Autohemolysis in fresh serum was $21.0 \%$ and in jaundiced sera it averaged $11.6 \%$. Thus, autohemolysis, which results from both colloid osmotic swelling and the loss of membrane lipid (37), is reduced by factors that cause lipid to accumulate in the red cell membrane.

\section{DISCUSSION}

These studies demonstrate that HS red cells are deficient in lipid and surface area both before and after splenectomy. They acquire membrane lipid in obstructive jaundice, and this extends their surface area and permits them to survive longer in vivo.

Red cell lipids in patients with hemolysis, as in HS before splenectomy, must be compared with normal red cells of comparable age, since younger cells have a 10$15 \%$ greater content of both cholesterol and phospholipid $(38,39)$. Thus, the small apparent decrement in lipid in two patients with HS and intact spleens reported here becomes magnified when cell age is taken into consideration, and the average decrease of $7 \%$ may then represent a true decrease of $15-20 \%$. This same consideration does not apply to HS red cells after splenectomy, where normal or only slightly shortened red cell survivals have been demonstrated $(1,40-42)$.

However, splenectomy itself influences the red cell membrane. The occurrence of target cells with increased surface area after splenectomy parallels the acquisition of osmotic resistance (43), and both evolve to a maximum over several weeks to several months $(15,44,45)$. As demonstrated above, these changes are associated with a membrane lipid content in excess of that present in subjects with spleens. When red cells from patients with HS who have undergone splenectomy are compared 
with red cells from subjects who do not have HS but who also have undergone splenectomy, a deficiency of lipid is seen in HS red cells and this deficiency involves both cholesterol and phospholipid.

Lipid is acquired by HS red cells in obstructive jaundice, either in vitro or in vivo, and this leads to an increase in the cell's surface area-to-volume ratio. A1though not measured, this increase probably enhances the cell's deformability and allows the cell to traverse the spleen more efficiently. As in the patient reported herein, this acquisition of lipid consists primarily of cholesterol, although phospholipid is usually gained as well $(12,18,21)$. The mechanism of this lipid acquisition has been related to both a decrease in the activity of the serum cholesterol esterifying enzyme, acyltransferase, and to a bile salt mediated transfer of cholesterol from serum lipoproteins to red cell membranes (12). Although the addition of lipid to HS cells increased their surface-to-volume ratio and enhanced their survival, Crosby and Conrad reported no change in HS cell survival when this ratio was increased through the induction of iron deficiency (46). The difference in experimental design makes it difficult to compare these two studies.

The membrane lipid alterations observed upon incubation of red cells, as reported in this and another study, ${ }^{1}$ demonstrate that, at a low hematocrit in serum supplemented with glucose, HS cells either gain or lose cholesterol depending on the nature of the serum present. However, they do not undergo a change in their content of phospholipid. In contrast, studies have been reported in which HS cells lost both cholesterol and phospholipid in equivalent amounts during incubation for as little as $4 \mathrm{hr}$ under conditions of adequate glucose, but in buffer rather than serum (47), and this loss was attributed to the increased sodium flux which HS cells maintain. When incubated in serum but in the absence of glucose, however, HS red cells have lost both cholesterol and phospholipid ${ }^{1}$ (5). Thus, in serum systems, glucose deprivation, as might occur under conditions of erythroconcentration in the spleen (10), rather than sodium pumping, appears to be the cause of the combined cholesterol-phospholipid loss in HS.

Although, after splenectomy HS red cells are deficient in lipid when compared with red cells from subjects without HS who have also undergone splenectomy, they nonetheless have a lipid content that is similar to that of red cells from normal subjects whose spleens are intact. Despite this similarity, red cells from HS patients without spleens are more osmotically fragile than red cells from normal subjects with spleens. This implies a factor other than lipid deficiency, per se, to explain the de-

\footnotetext{
${ }^{1}$ Cooper, R. A., and J. H. Jandl. The selective and conjoint loss of red cell lipids. Submitted for publication.
}

ficiency in surface area. Possibly the red cell membrane should not be considered as homogeneous. Rather, the specific lipid deficiency in HS may lead to a reorientation of membrane structural subunits such that they provide less surface per unit of lipid than normal. Increased sodium permeability may result from this reorientation. Whereas lipid can be added to HS red cells in obstructive jaundice with a proportional increase in membrane surface area, such an addition does not apparently include the specific constituents necessary for a normal subunit orientation. The lack of change in glucose consumption and sodium efflux by HS red cells incubated in obstructive jaundice serum in spite of an increase in their membrane lipid content is consistent with this view. On the other hand, the increased surface that results from lipid addition allows the HS cell to traverse better the splenic circulation. Moreover, it permits more colloid osmotic swelling and therefore leads to a decreased autohemolysis.

The transient decrease in osmotic fragility and increase in red cell cholesterol noted in our patient during an episode of biliary obstruction was too brief to allow studies of red cell survival. Diamond, ${ }^{2}$ however, recalls two children with HS who, during an episode of obstructive jaundice, had a shift in their osmotic fragility curves to normal and a remission from their hemolytic anemia, with return of hemoglobin and reticulocytes to normal levels. The transfusion studies reported herein confirm these observations and serve to emphasize the relationship between the shape and survival of red cells in hereditary spherocytosis.

\section{ACKNOWLEDGMENTS}

The authors are grateful to the following physicians for referring patients for study: Doctors G. Blum, J. Desforges, M. Greenberg, W. Keene, B. Rosen, L. Talarico, J. Truman, and S. Shohet.

The authors are also grateful to Miss E. Streif, Miss J. Nordberg, and Miss C. Buzas for their technical assistance and to Miss W. N. Sheldon and Miss T. Stenberg for their secretarial assistance. Art work was prepared by Arrco, Inc., Boston, Mass.

These studies were supported in part by grants HE- 07652 and T1-AM-5391 from the National Institutes of Health, U. S. Public Health Service research grant Fr-76 from the Division of Research Facilities and Resources, National Institutes of Health, Research Fellowship grant 1-F3-AM38, 345 from the U. S. Public Health Service, and Career Development award K3-HE-3943 from the National Heart Institute, Bethesda, Md.

\section{REFERENCES}

1. Emerson, C. P., S. C. Shen, T. H. Ham, E. M. Fleming, and W. B. Castle. 1956. Studies on the destruction of red blood cells. IX. Quantitative methods for determining the

\footnotetext{
${ }^{2}$ Diamond, L. K. Personal communication.
} 
osmotic and mechanical fragility of red cells in the peripheral blood and splenic pulp; the mechanism of increased hemolysis in hereditary spherocytosis (congenital hemolytic jaundice) as related to the function of the spleen. Arch. Intern. Med. 97: 1.

2. Young, L. E. 1955. Hereditary spherocytosis. Amer. J. Med. 18: 486.

3. Dacie, J. V. 1960. The Hemolytic Anemias. Congenital and Acquired. Part I. The congenital anaemias. Grune \& Stratton, New York. 2nd edition. 82.

4. Jacob, H. S., and J. H. Jandl. 1964. Increased cell membrane permeability in the pathogenesis of hereditary spherocytosis. J. Clin. Invest. 43: 1704.

5. Reed, C. F., and S. N. Swisher. 1966. Erythrocyte lipid loss in hereditary spherocytosis. J. Clin. Invest. 45: 777.

6. Murphy, J. R. 1967. The influence of $\mathrm{pH}$ and temperature on some physical properties of normal erythrocytes and erythrocytes from patients with hereditary spherocytosis. J. Lab. Clin. Med. 69: 758.

7. Griggs, R. C., R. Weisman, and J. W. Harris. 1960. Alterations in osmotic and mechanical fragility related to in vivo erythrocyte aging and splenic sequestration in hereditary spherocytosis. J. Clin. Invest. 39: 89.

8. Whipple, A. O. 1941. Recent studies in the circulation of the portal bed and of the spleen in relation to splenomegaly. Trans. Stud. Coll. Physicians Philadelphia. 8: 203.

9. Bjorkman, S. E. 1947. The splenic circulation. Acta Med. Scand. Suppl. 191.

10. Jandl, J. H., and R. H. Aster. 1967. Increased splenic pooling and the pathogenesis of hypersplenism. Amer. J. Med.Sci. 253: 383.

11. Murphy, J. R. 1962. Erythrocyte metabolism. III. Relationship of energy metabolism and serum factors to the osmotic fragility following incubation. J. Lab. Clin. Med. 60: 86.

12. Cooper, R. A., and J. H. Jand1. 1968. Bile salts and cholesterol in the pathogenesis of target cells in obstructive jaundice. J. Clin. Invest. 47: 809 .

13. Phillips, G. B., and N. S. Roome. 1962. Quantitative chromatographic analysis of the phospholipids of abnormal human red blood cells. Proc. Soc. Exp. Biol. Med. 109: 360 .

14. Bradlow, B. A., J. Lee, and R. Rubenstein. 1965. Erythrocyte phospholipids: quantitative thin layer chromatography in paroxysmal nocturnal haemoglobinuria and hereditary spherocytosis. Brit. J. Haematol. 11: 315.

15. Singer, K., E. B. Miller, and W. Dameshek. 1941. Hematological changes following splenectomy in man, with particular reference to target cells, hemolytic index and lysolecithin. Amer. J. Med. Sci. 202: 171.

16. Hagerman, J. S., and R. G. Gould. 1951. The in vitro interchange of cholesterol between plasma and red cells. Proc. Soc. Exp. Biol. Med. 78: 329.

17. Reed, C. F. 1968. Phospholipid exchange between plasma and erythrocytes in man and the dog. J. Clin. Invest. $47: 749$.

18. Neerhout, R. C. 1968. Abnormalities of erythrocyte stromal lipids in hepatic disease. J. Lab. Clin. Med. 71: 438.

19. Ways, P. 1967. An acquired reversible abnormality of erythrocyte lipids associated with liver disease and hemolytic anemia. J. Clin. Invest. 46: 1129. (Abstr.)

20. Smith, J. A., E. T. Lonergan, and K. Sterling. 1964. Spur-cell anemia. Hemolytic anemia with red cells resembling acanthocytes in alcoholic cirrhosis. New Engl. J. Med. 271: 396.

21. Brun, G. C. 1939. Cholesterol content of red blood cells in man. Acta Med. Scand. Suppl. 99.

22. Daland, G. A., S. M. Shea, W. H. Baker, and L. B. Page. 1960. Methods for the study of the morphology of blood. In A Syllabus of Laboratory Examinations in Clinical Diagnosis. L. B. Page and P. J. Culver, editors. Harvard University Press, Cambridge. 71.

23. Rose, H. G.. and M. Oklander. 1965. Improved procedure for the extraction of lipids from human erythrocytes. J. Lipid Res. 6: 428.

24. Zlatkis, A., B. Zak, and A. J. Boyle. 1953. A new method for the direct determination of serum cholesterol. J. Lab. Clin. Med. 41: 486.

25. Bartlett, G. R. 1959. Phosphorus assay in column chromatography. J. Biol. Chem. 234: 466.

26. Young, L. E., M. J. Izzo, K. I. Altman, and S. N. Swisher. 1956. Studies on spontaneous in vitro autohemolysis in hemolytic disorders. Blood. 11: 977.

27. Saifer, A., and S. Gerstenfeld. 1958. The photometric microdetermination of blood glucose with glucose oxidase. J. Lab. Clin. Med. 51: 448.

28. Jandl, J. H., M. S. Greenberg, R. H. Yonemoto, and W. B. Castle. 1956. Clinical determination of the sites of red cell sequestration in hemolytic anemias. J. Clin. Invest. 35: 842 .

29. Mollison, P. L. 1967. Blood Transfusion in Clinical Medicine. F. A. Davis Company, Philadelphia. 4th edition. 456.

30. Jandl, J. H. 1959. Modern views of immunohematology. In Proceedings of the 7 th International Congress of the International Society of Hematology, Rome. 7 September 1958. Grune \& Stratton Inc., N. Y. 1: 45.

31. Ham. T. H., S. C. Shen, E. M. Fleming, and W. B. Castle. 1948. Thermal injury: action of heat in causing increased spheroidicity, osmotic and mechanical fragilities and hemolysis of erythrocytes; observations on the mechanisms of destruction of such erythrocytes in dogs and in a patient with a fatal thermal burn. Blood. 3: 373.

32. Marsh, G. W., S. M. Lewis, and L. Szur. 1966. The use of ${ }^{51} \mathrm{Cr}$-labeled heat damaged red cells to study splenic function. I. Evaluation of method. Brit. J. Haematol. 12: 161.

33. Kimber, R. J., and H. Lander. 1964. The effect of heat on human red cell morphology, fragility, and subsequent survival in vivo. J. Lab. Clin. Med. 64: 922.

34. Chanel, L. 1880. Récherchés sur la résistance des hematies. These Doct. de Lyons. (Quoted by C. M'Neil.) 1910. In The Resistance of Human Red Corpuscles in Health and Disease to Hemolysis by Saponin. J. Pathol. Bacteriol. 15: 86 .

35. Bertles, J. F. 1957. Sodium transport across the surface membrane of red blood cells in hereditary spherocytosis. J. Clin. Invest. 36: 816.

36. Mohler, D. N. 1965. Adenosine triphosphate metabolism in hereditary spherocytosis. J. Clin. Invest. 44: 1417.

37. Weed, R. I., and A. J. Bowdler. 1966. Metabolic dependence of the critical hemolytic volume of human erythrocytes: relationship to osmotic fragility and autohemolysis in hereditary spherocytosis and normal red cells. J. Clin. Invest. 45: 1137.

38. Westerman, M. P., L. E. Pierce, and W. N. Jensen. 1963. Erythtrocyte lipids : a comparison of normal young and normal old populations. J. Lab. Clin. Med. 62: 394. 
39. van Gastel, C., D. van Den Berg, J. De Gier, and L. L. M. van Deenen. 1965. Some lipid characteristics of normal red blood cells of different age. Brit. J. Haematol. 11 : 193.

40. Schrumpf, C. A. A. 1951. Role of the spleen in familial spherocytosis. Proc. 3rd Intern. Congr. Intern. Soc. Hematol. Grune and Stratton, Inc., New York. 94.

41. Read, R. C., G. W. Wilson, and F. H. Gardner. 1954. Use of radioactive sodium chromate to evaluate the life span of the red blood cell in health and certain hematologic disorders. Amer. J. Med. Sci. 228: 40.

42. Chapman, R. G. 1968. Red cell life span after splenectomy in hereditary spherocytosis. J. Clin. Invest. 47: 2263.

43. Barrett, A. M. 1938. A special form of erythrocyte possessing increased resistance to hypotonic saline. $J$. Pathol. Bacteriol. 46: 603.

44. Tsai, C., J-S Lee, and C. H. Wu. 1940. The role of splenic action in altering erythrocyte fragility. Chinese J. Physiol. 15: 165.

45. Miller, E. B., K. Singer, and W. Dameshek. 1942. Experimental production of target cells by splenectomy and interference with splenic circulation. Proc. Soc. Exp. Med. Biol. 49: 42.

46. Crosby, W. H., and M. E. Conrad. 1960. Hereditary spherocytosis: observations on hemolytic mechanisms and iron metabolism. Blood. 15: 662 .

47. Jacob. H. S. 1967. Membrane lipid depletion in hyperpermeable red blood cells: its role in the genesis of spherocytes in hereditary spherocytosis. J. Clin Invest. 46: 2083. 